\title{
Konsumsi sagu keluarga berdasarkan preferensi dan persepsi nilai sosial sagu keluarga di Kabupaten Konawe Provinsi Sulawesi Tenggara
}

\author{
Imanuddin ${ }^{1}$, Abidillah Mursyid², Joko Susilo ${ }^{3}$
}

\begin{abstract}
Background: Variety of staple foods has an important role in supporting food security of the community. However, more people who used to consume non rice turn to consume rice nowadays. Sago (sinonggi) as one of staple foods is consumed less every year in Sulawesi Tenggara. This may be due to some factors, among others are preferences of the community to sago, perception of the community about social value of sago and sago availability.

Objective: To identify the consumption of sago of the family in relation to preferences and perception of the family about social value of sago, availability of sago in the family level and its distribution.

Method: The study was observational with cross sectional design. Research location was determined using cluster stratified random sampling technique. Three subdistricts represented category of far, medium, and close from district capital. Two villages represented category of close and far from subdistrict capital. Distribution of 196 households samples were taken with proportionate sampling technique in 6 chosen villages. Variables of the study consisted of preferences to sago, perception about social value of sago, sago consumption and availability of sago in the household. Data were obtained through structured interview using questionnaire and observation. Bivariable analysis used chi-square; whereas multivariable used logistic regression.
\end{abstract}

Results: Sago as complementary food of rice were consumed everyday by $65 \%$ of households. Preference level of sago was like (70.4\%) and favorite(29.6\%). Household perceived social value of sago as low (74.0\%) and not low (26.0\%). Sago was always available throughout the years at distribution level.

Conclusions: There were differences in the consumption of sago based on the family preferences of sago, the family perception of sago social values, and the household availability of sago. Sago availability in the household was the most dominant factor of sago consumption in the household.

KEY WORDS: sago, sinonggi, preferences, perception, social values, staple foods

\section{PENDAHULUAN}

Keragaman bahan pangan pokok sangat esensial untuk mendukung ketahanan pangan masyarakat dan menghindari ketergantungan terhadap suatu jenis bahan pangan tertentu. Dewasa ini terdapat kecenderungan masyarakat untuk beralih dari makanan pokok beras menjadi nonberas.

Sagu sebagai salah satu jenis bahan pangan pokok di Sulawesi Tenggara, konsumsinya terus menurun dari tahun ke tahun. Data tahun 1984 menunjukkan bahwa konsumsi sagu rata-rata di Provinsi Sulawesi Tenggara masih cukup tinggi yaitu sebesar $74,1 \mathrm{~g} /$ orang/hari (1). Tahun 2004 konsumsi sagu di provinsi tersebut terus menurun menjadi 8,6 g/orang/hari (2).

Penurunan konsumsi sagu ini juga terjadi di Kabupaten Konawe, yang merupakan produsen sagu terbesar di Sulawesi Tenggara. Menurut data terakhir yang ada dan dipublikasikan, konsumsi sagu di kabupaten ini masih cukup tinggi dengan frekuensi konsumsi 1-6 kali per minggu (3).

Konsumsi sagu masyarakat (dalam bentuk siap santap disebut sinonggi), seperti halnya makanan lain, dipengaruhi oleh banyak faktor, antara lain: tingkat kesukaaan (preferensi) terhadap sagu, persepsi terhadap nilai sosial sagu, dan ketersediaan sagu itu sendiri pada tingkat rumah tangga dan distribusi. Preferensi terhadap makanan dipengaruhi oleh karakteristik yang dimiliki suatu makanan, yang pada akhirnya menentukan tingkat penerimaan makanan bersangkutan (4). Makanan yang dipersepsikan memiliki nilai sosial yang rendah dapat menyebabkan konsumsinya menurun atau bahkan tidak dikonsumsi lagi, beralih ke jenis makanan lain yang dianggap memiliki nilai sosial lebih tinggi. Suhardjo (5) mengemukakan bahwa dalam masyarakat, berbagai jenis makanan dan bahan makanan mempunyai nilai sosial tertentu, sehingga masyarakat biasanya akan mengkonsumsi bahan makanan dan makanan tertentu yang mempunyai nilai sosial sesuai dengan tingkat naluri pangan yang terdapat pada masyarakat tersebut. Penduduk yang semula menggunakan bahan pangan pokok jagung, sagu, singkong, atau gaplek beralih ke nasi karena adanya kekuatan gengsi. Nasi dari beras dianggap

\footnotetext{
Jurusan Gizi Politeknik Kesehatan Departemen Kesehatan RI, Kendari 2 Politeknik Kesehatan Departemen Kesehatan RI, Yogyakarta

3 Jurusan Gizi Politeknik Kesehatan Departemen Kesehatan RI, Yogyakarta
} 
memiliki status sosial yang lebih tinggi daripada jagung, sagu, singkong, atau gaplek (6). Beras dipandang sebagai bahan pangan superior, sebaliknya umbi-umbian, jagung, dan sagu sebagai bahan pangan inferior (7). Ketersediaan bahan pangan mempengaruhi preferensi kaitannya dengan akses keterjangkauan secara berkesinambungan bahan pangan tersebut. Menurut Sanjur (8) ketersediaan ini dapat berada pada tingkat nasional, wilayah, masyarakat (distribusi) dan rumah tangga.

Penelitian ini bertujuan untuk mengetahui perbedaan konsumsi sagu keluarga berdasarkan tingkat preferensi dan persepsi nilai sosial sagu keluarga, serta ketersediaan sagu pada tingkat rumah tangga dan distribusi. Hipotesis penelitian adalah: ada perbedaan konsumsi sagu keluarga berdasarkan tingkat preferensi keluarga terhadap sagu,ada perbedaan konsumsi sagu keluarga berdasarkan persepsi keluarga terhadap nilai sosial sagu,ada perbedaan konsumsi sagu keluarga berdasarkan tingkat ketersediaan sagu di rumah tangga.

\section{BAHAN DAN METODE}

Penelitian ini merupakan penelitian observasional menggunakan rancangan cross sectional, dilaksanakan pada bulan Juni sampai Desember 2006 di Kabupaten Konawe Provinsi Sulawesi Tenggara. Populasi adalah rumah tangga pada enam desa di tiga kecamatan yang masing-masing mewakili kecamatan dengan jarak dekat, sedang, dan jauh dari ibukota kabupaten. Besar sampel minimal dihitung menggunakan rumus Lemeshow et al. (9) dan diperoleh 196 rumah tangga. Penentuan sampel secara random dan terdistribusi secara proporsional pada 6 desa. Kriteria inklusi meliputi rumah tangga dengan suku bangsa Tolaki (penduduk asli Kabupaten Konawe) dan ibu rumah tangga yang bersedia diikutkan dalam penelitian.

Pengumpulan data dilakukan dengan wawancara terstruktur menggunakan kuesioner dan pengamatan langsung. Variabel penelitian meliputi: konsumsi sagu, preferensi terhadap sagu, persepsi nilai sosial sagu, dan ketersediaan sagu di rumah tangga.

Pengolahan dan analisis data menggunakan perangkat lunak komputer. Analisis data dilakukan secara bertahap, didahului dengan analisis univariat kemudian dilanjutkan dengan analisis bivariat dan multivariat. Analisis bivariat menggunakan uji statistik chi square $\left(\chi^{2}\right)$ dan analisis multivariat menggunakan uji regresi logistik.

\section{HASIL}

\section{Konsumsi sagu rumah tangga}

Dari sejumlah rumah tangga sampel, seluruhnya $(100,0 \%)$ biasa mengkonsumsi sagu dengan frekuensi konsumsi 1 sampai 17 kali per minggu. Sebagian besar $(67,5 \%)$ rumah tangga menghidangkan sagu dalam bentuk sinonggi setiap hari, selebihnya 1-5 kali per minggu. Berdasarkan klasifikasi tingkat konsumsi sagu pada penelitian ini, sebagian besar rumah tangga berada dalam kategori sering mengkonsumsi sagu $(43,9 \%)$, selanjutnya dalam kategori jarang $(32,1 \%)$ dan sedang $(24,0 \%)$.

\section{Preferensi terhadap sagu}

Preferensi terhadap sagu digolongkan dalam 4 kategori, yaitu: tidak suka, kurang suka, suka, dan sangat suka. Dalam penelitian ini, preferensi rumah tangga terhadap sagu berada dalam kisaran suka $(70,4 \%)$ sampai sangat suka $(29,6 \%)$. Tidak terdapat rumah tangga yang menyatakan kurang dan tidak suka terhadap sagu.

Penilaian terhadap atribut sagu dalam bentuk sinonggi yang meliputi rasa, penampilan, tingkat kemudahan pengolahan/penyajian, dan harga menunjukkan tanggapan yang relatif sama di antara rumah tangga. Dalam hal atribut rasa dan tingkat kemudahan pengolahan/penyajian, keseluruhan rumah tangga $(100,0 \%)$ mengemukakan bahwa rasa sagu dalam bentuk sinonggi enak dan mudah dalam pengolahan/ penyajiannya. Demikian pula dalam hal penampilan dan harga, sebagian besar rumah tangga berturut-turut sebanyak $99,5 \%$ dan $98 \%$ mengemukakan bahwa penampilan sagu dalam bentuk sinonggi menarik dan harga sagu lebih murah dibandingkan harga beras.

\section{Persepsi terhadap nilai sosial sagu}

Persepsi rumah tangga terhadap nilai sosial sagu dalam penelitian ini dikelompokkan dalam 2 kategori, yaitu rendah dan tidak rendah. Persepsi yang tidak rendah diartikan bahwa nilai sosial sagu tidak lebih rendah daripada bahan pangan pokok lainnya yang biasa dikonsumsi. Hasil dalam penelitian ini, menunjukkan bahwa sebagian besar sampel $(74,0 \%)$ mempersepsikan nilai sosial sagu rendah, selebihnya $(26,0 \%)$ mempersepsikan nilai sosial sagu tidak lebih rendah dibanding bahan pangan pokok lainnya yang biasa dikonsumsi.

Pada penelitian ini sebesar 95,9\% rumah tangga menilai bahwa makanan yang paling pantas dikonsumsi oleh pejabat pemerintah seperti camat atau bupati adalah nasi. Hal yang sama sebesar $94,4 \%$ rumah tangga menilai orang yang dianggap kaya dari segi ekonomi lebih pantas makan nasi daripada sinonggi. Pada saat acara pesta yang diselenggarakan oleh keluarga, sebesar $72,4 \%$ rumah tangga menganggap sinonggi tidak layak dihidangkan. Begitu pula pada saat hari raya keagamaan seperti Idul Fitri, sebesar 29,1\% rumah tangga menyatakan sinonggi tidak layak dihidangkan. 
Dalam hal komersialisasi sagu, sebesar $72,4 \%$ rumah tangga menyatakan sagu tidak layak dijual di warung makan dan $92,3 \%$ menyatakan bahwa harga jual sagu tidak layak bila sama atau lebih mahal daripada beras.

Rumah tangga merasa malu menghidangkan sagu dalam bentuk sinonggi kepada tamu yang baru dikenalnya. Pada penelitian ini, 53,1\% rumah tangga berupaya agar sinonggi tidak terlihat oleh tamu, walaupun rumah tangga tersebut sebenarnya biasa mengkonsumsi sinonggi.

Persepsi rumah tangga terhadap nilai sosial sagu tidak berbeda berdasarkan tingkat pendidikan sampel, pekerjaan kepala keluarga, dan berdasarkan tingkat perdapatan per kapita keluarga $(p<0,05)$.

\section{Ketersediaan sagu pada tingkat rumah tangga dan} distribusi

Ketersediaan sagu pada tingkat rumah tangga. Seluruh rumah tangga sampel $(100,0 \%)$ mengadakan sagu sebanyak 1 sampai $15 \mathrm{~L}$ per minggu, dengan ratarata $7,12 \pm 4,2 \mathrm{~L}$. Pengadaan sagu dalam rumah tangga ini, sebagian besar $(92,4 \%)$ melalui cara membeli, selebihnya dengan cara memproduksi sendiri $(7,1 \%)$ dan gabungan antara membeli dan produksi sendiri $(0,5 \%)$.

Ketersediaan sagu pada tingkat distribusi. Semua sampel (pedagang sagu) menyatakan bahwa, sagu selalu ada yang diperjualbelikan sepanjang tahun pada setiap pasar yang ada di sekitar daerah penelitian ini.

Perbedaan konsumsi sagu rumah tangga berdasarkan tingkat preferensi sagu, persepsi nilai sosial sagu, dan berdasarkan ketersediaan sagu dalam rumah tangga

Preferensi terhadap sagu dan konsumsi sagu rumah tangga. Hasil penelitian ini menunjukkan bahwa rumah tangga dengan tingkat preferensi suka terhadap sagu, sebagian besar $(37,7 \%)$ sering mengkonsumsi sagu, selanjutnya jarang dan sedang. Demikian pula rumah tangga dengan tingkat preferensi sangat suka terhadap sagu, sebagian besar $(58,6 \%)$ sering mengkonsumsi sagu, selanjutnya jarang dan sedang (Tabel 1).

Persepsi nilai sosial sagu dan konsumsi sagu rumah tangga. Rumah tangga yang mempersepsikan nilai sosial sagu rendah, sebagian besar $(46,2 \%)$ sering mengkonsumsi sagu, selanjutnya jarang dan sedang. Sedangkan rumah tangga yang mempersepsikan nilai sosial sagu tidak rendah, sebagian besar $(49,0 \%)$ mengkonsumsi sagu dalam kategori sedang, selanjutnya sering dan jarang (Tabel 2).

Ketersediaan sagu dalam rumah tangga dan konsumsi sagu rumah tangga. Rumah tangga dengan tingkat ketersediaan sagu yang tergolong rendah, sebagian besar $(78,1 \%)$ jarang mengkonsumsi sagu, selanjutnya sering dan sedang. Sedangkan rumah tangga dengan tingkat ketersediaan sagu yang tergolong tinggi, sebagian besar $(61,0 \%)$ sering mengkonsumsi sagu, selanjutnya sedang dan jarang (Tabel 3 ).

\section{Analisis Multivariat}

Untuk melakukan analisis ini, semua variabel dikelompokkan dalam 2 kategori (dikotomus), sehingga variabel tingkat konsumsi sagu yang sebelumnya dikelompokkan dalam 3 kategori (rendah, sedang, dan tinggi), dimodifikasi menjadi kategori rendah dan tinggi (kategori sedang digabungkan ke dalam kategori tinggi). Konsumsi sagu berdasarkan preferensi, persepsi nilai sosial, dan ketersediaan sagu dalam rumah tangga,

TABEL 1. Frekuensi konsumsi sagu menurut tingkat preferensi terhadap sagu

\begin{tabular}{|c|c|c|c|c|c|c|c|c|c|c|}
\hline \multirow{3}{*}{$\begin{array}{c}\text { Preferensi } \\
\text { terhadap sagu }\end{array}$} & \multicolumn{6}{|c|}{ F rekuensi konsumsi sagu } & \multirow{2}{*}{\multicolumn{2}{|c|}{ Total }} & \multirow{3}{*}{$\boldsymbol{x}^{2}$} & \multirow{3}{*}{ p } \\
\hline & \multicolumn{2}{|c|}{ har ang } & \multicolumn{2}{|c|}{ Sedang } & \multicolumn{2}{|c|}{ Sering } & & & & \\
\hline & $\mathbf{n}$ & $\%$ & $\mathbf{n}$ & $\%$ & $\mathbf{n}$ & $\%$ & n & $\%$ & & \\
\hline Suka & 50 & 36,2 & 36 & 26,1 & 52 & 37,7 & 138 & 100 & 7,370 & $0,025^{\prime}$ \\
\hline Sangat suka & 13 & 22,4 & 11 & 19,0 & 34 & 58.6 & 58 & 100 & & \\
\hline Total & 63 & 321 & 47 & 24,0 & 86 & 43,9 & 196 & 100 & & \\
\hline
\end{tabular}

TABEL 2. Frekuensi konsumsi sagu menurut persepsi terhadap nilai sosial sagu

\begin{tabular}{|c|c|c|c|c|c|c|c|c|c|c|}
\hline \multirow{3}{*}{$\begin{array}{c}\text { Persepsi } \\
\text { nilai sosial } \\
\text { sagu }\end{array}$} & \multicolumn{6}{|c|}{ Frekuensi konsumsi sagu } & \multirow{2}{*}{\multicolumn{2}{|c|}{ Total }} & \multirow{3}{*}{$x^{2}$} & \multirow{3}{*}{$\mathbf{p}$} \\
\hline & \multicolumn{2}{|c|}{ Jarang } & \multicolumn{2}{|c|}{ Sedang } & \multicolumn{2}{|c|}{ Sering } & & & & \\
\hline & $n$ & $\%$ & $\mathbf{n}$ & $\%$ & $\mathrm{n}$ & $\%$ & $n$ & $\%$ & & \\
\hline Rendah & 56 & 38,6 & 22 & 15,2 & 67 & 46,2 & 135 & 100 & 25,989 & $0,000^{*}$ \\
\hline Tidak rendah & 7 & 13,7 & 25 & 49,0 & 19 & 37,3 & 51 & 100 & & \\
\hline Total & 63 & 32,1 & 47 & 24,0 & 86 & 43,9 & 196 & 100 & & \\
\hline
\end{tabular}


TABEL 3. Frekuensi konsumsi sagu menurut tingkat ketersediaan sagu dalam rumah tangga

\begin{tabular}{|c|c|c|c|c|c|c|c|c|c|c|}
\hline \multirow{3}{*}{$\begin{array}{l}\text { Ketersediaan } \\
\text { sagu dalam } \\
\text { rumah tangga }\end{array}$} & \multicolumn{6}{|c|}{ Frekuensi konsumsi sagu } & \multirow{2}{*}{\multicolumn{2}{|c|}{ Total }} & \multirow{3}{*}{$\chi^{2}$} & \multirow{3}{*}{$\mathbf{p}$} \\
\hline & \multicolumn{2}{|c|}{ Jarang } & \multicolumn{2}{|c|}{ Sedang } & \multicolumn{2}{|c|}{ Sering } & & & & \\
\hline & $\mathbf{n}$ & $\%$ & $n$ & $\%$ & $\mathbf{n}$ & $\%$ & $\mathbf{n}$ & $\%$ & & \\
\hline Rendah & 57 & 78,1 & 5 & 6,8 & 11 & 15,1 & 73 & 100 & 112,61 & $0,000^{\star}$ \\
\hline Tinggi & 6 & 4,9 & 42 & 34,1 & 75 & 61,0 & 123 & 100 & & \\
\hline Total & 63 & 32,1 & 47 & 24,0 & 86 & 43,9 & 196 & 100 & & \\
\hline
\end{tabular}

setelah variabel konsumsi sagu dimodifikasi menjadi 2 kelompok disajikan pada Gambar 1.

Hasil pengujian variabel independen secara bersamasama menunjukkan bahwa variabel yang dominan mempengaruhi konsumsi sagu rumah tangga adalah ketersediaan sagu dalam rumah tangga $(p<0,05)$ dengan nilai OR $(\operatorname{Exp} B)=0,013(\mathrm{IK} \mathrm{95 \% =0,004-0,039)}($ Tabel 4).

Berdasarkan nilai OR (Exp B), variabel ketersediaan sagu sebagai faktor protektif, kelompok rumah tangga dengan tingkat ketersediaan sagu yang tergolong rendah berpeluang mengkonsumsi sagu dalam kategori sering sebesar 0,013 kali lebih besar dibandingkan dengan rumah tangga dengan tingkat ketersediaan sagu yang tergolong tinggi. Namun demikian, peluang ini sangat kecil yaitu hanya 0,013 atau kurang lebih seperseratus kali.

Nilai OR (Exp B) variabel preferensi sagu sebesar 0,930 (IK 95\% 0,311-2,783) dan variabel persepsi nilai sosial sagu sebesar 1,519 (IK 95\% 0,382-6,045). Kedua variabel ini bersifat netral yaitu tidak sebagai faktor risiko dan juga tidak sebagai faktor protektif terhadap konsumsi sagu , karena interval kepercayaan (IK 95\%) kedua variabel ini mencakup angka 1 (10).

\section{BAHASAN}

\section{Konsumsi sagu rumah tangga}

Konsumsi sagu rumah tangga sampel yang masih tergolong tinggi dapat berkaitan dengan kebiasaan makan yang telah terbentuk sejak usia dini (5). Dalam hal kebiasaan makan rumah tangga, sagu mulai diperkenalkan sebagai salah satu makanan sumber karbohidrat kepada anggota rumah tangga sampel sejak usia balita sebesar $65,8 \%$, selebihnya $(34,2 \%)$ diperkenalkan pada usia 6-7 tahun. Kebiasaan makan sagu ini menjadi pola perilaku konsumsi karena terjadi berulang-ulang dalam waktu lama, yaitu sejak masa

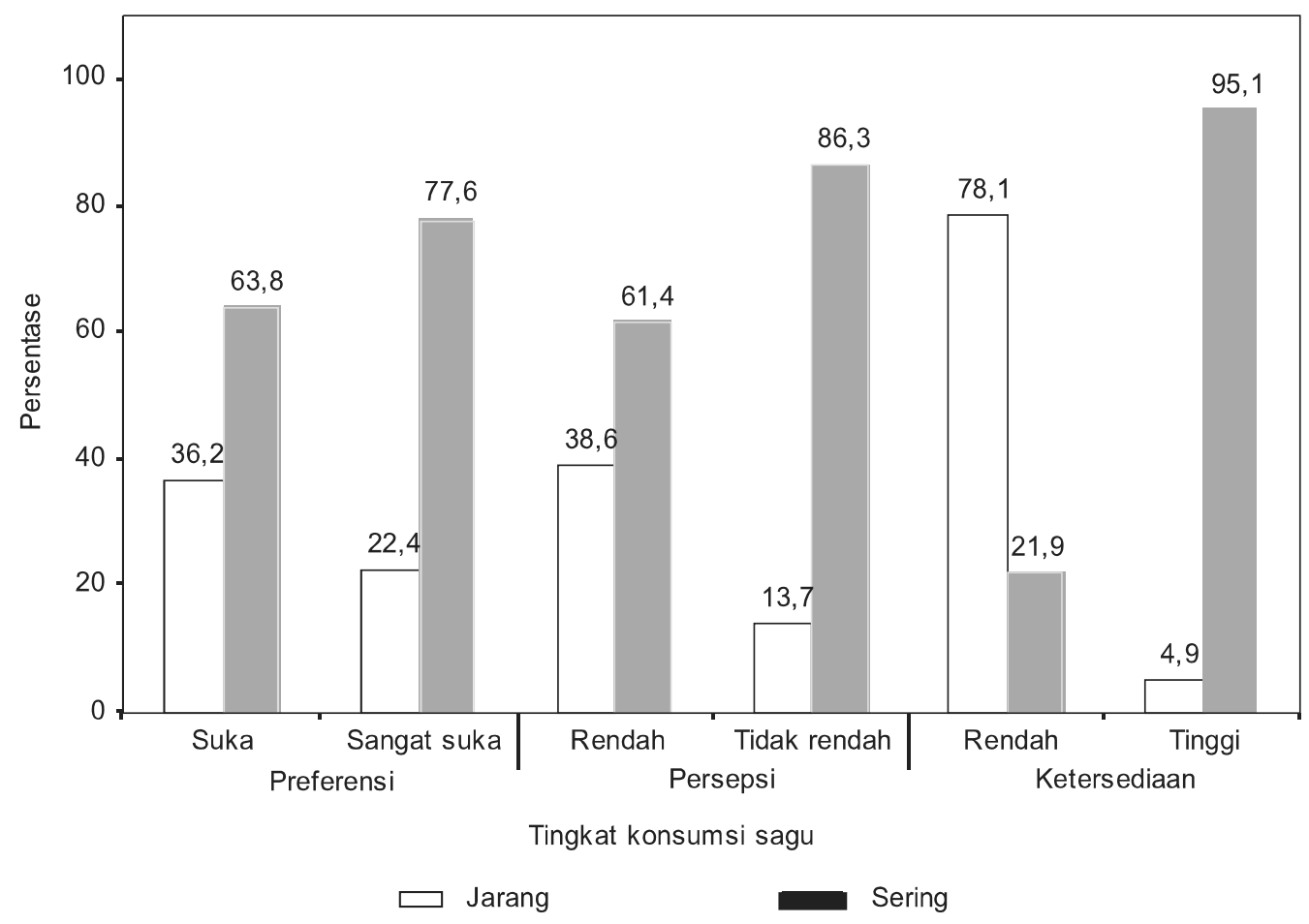

Gambar 1. Konsumsi sagu berdasarkan preferensi, persepsi nilai sosial dan ketersediaan sagu 
TABEL 4. Hasil analisis multivariat regresi logistik

\begin{tabular}{lccccccc}
\hline \multicolumn{1}{c}{ Variabel } & B & SE & Wald & df & Sig & Exp (B) & IK 95\% \\
\hline Preferensi & $-0,073$ & 0,559 & 0,017 & 1 & 0,897 & 0,930 & $0,311-2,783$ \\
Persepsi & 0,418 & 0,705 & 0,353 & 1 & 0,553 & 1,519 & $0,382-6,045$ \\
Ketersediaan & $-4,378$ & 0,583 & 56,482 & 1 & $0,000^{*}$ & 0,013 & $0,004-0,039$ \\
\hline
\end{tabular}

Keterangan:

* Signifikan $(p<0,05)$

kanak-kanak (11). Hal ini sekaligus menunjukkan bahwa kebiasaan makan sagu dalam rumah tangga sampel bukan karena proses pendidikan atau sengaja dipelajari (unlearned), tetapi lebih bersifat inherited yakni diturunkan dari orang tua atau generasi sebelumnya (8).

Selain diturunkan dari generasi sebelumnya, kebiasan makan sagu dalam rumah tangga sampel, didukung oleh ketersediaan pangan ini dalam masyarakat/ distribusi yang pada akhirnya menentukan ketersediaan dalam rumah tangga (5). Pada penelitian ini terungkap bahwa sagu selalu tersedia sepanjang tahun di pasarpasar sekitar daerah penelitian. Hal ini sekaligus memberi informasi bahwa tanaman sagu masih dikembangkan oleh masyarakat di Kabupaten Konawe.

Pada penelitian ini diketahui bahwa berdasarkan frekuensi konsumsi sagu pada rumah tangga sampel, sagu masih termasuk sebagai salah satu bahan pangan penting dalam susunan hidangan sehari-hari, tetapi tidak menjadi bahan pangan pokok, hanya sebagai pendamping bahan pangan pokok keluarga sampel. Suatu jenis makanan menjadi bahan pangan pokok, apabila bahan pangan tersebut dihidangkan dalam menu sehari-hari dan menempati porsi terbesar dalam hidangan, serta merupakan sumber utama energi. Kedudukan serta peranan bahan pangan pokok dalam susunan hidangan sehari-hari pada umumnya dominan terhadap bahan pangan lainnya, sebaliknya bahan pangan tambahan sifatnya hanya sebagai penunjang (6). Dalam penelitian ini, porsi terbesar dalam hal kuantum dan sumber utama energi ditempati oleh nasi.

Konsumsi sagu ini sangat penting untuk tetap dipertahankan guna menghindari ketergantungan pada salah satu jenis bahan pangan pokok yaitu beras. Diversifikasi bahan pangan pokok menggunakan sagu sangat mungkin diterapkan pada masyarakat Kabupaten Konawe karena sagu telah lama dikenal, dapat diterima sesuai selera masyarakat Kabupaten Konawe, serta jenis tanaman ini tumbuh dengan baik sesuai kondisi wilayah Kabupaten Konawe.

\section{Preferensi terhadap sagu}

Preferensi terhadap suatu makanan didefinisikan sebagai derajat suka atau tidak suka seseorang terhadap suatu makanan, yang dipengaruhi oleh karakteristik individu, karakteristik makanan, dan karakteristik lingkungan (8). Derajat kesukaan terhadap suatu makanan dapat diukur secara verbal, dengan skala, ataupun melalui ekspresi wajah (12).

Pada penelitian ini, preferensi rumah tangga terhadap sagu berada pada kisaran suka sebesar $70,4 \%$ sampai sangat suka sebesar $29,6 \%$. Tingkat penerimaan ini sejalan dengan penilaian rumah tangga terhadap atribut sagu dalam bentuk sinonggi yaitu berupa ciri-ciri organoleptik. Manusia mengkonsumsi sesuatu makanan karena makanan itu mampu memenuhi selera dan ciriciri organoleptik yang meliputi rasa, bau, suhu, penampilan dan tekstur yang mempengaruhi seseorang untuk menerima atau menolak suatu makanan (13). Hal yang sama juga dilaporkan oleh Candraningsih dan Sumarwan (14) tentang preferensi dan persepsi konsumen terhadap makanan tradisional Sunda yang membuktikan bahwa tingkat preferensi konsumen terhadap makanan tradisional berkaitan dengan persepsi konsumen terhadap atribut rasa, harga, penampilan, dan kecepatan penyajian /pengolahan.

Semua rumah tangga dalam penelitian ini menilai bahwa rasa sagu dalam bentuk sinonggi enak dan mudah dalam hal pengolahan/penyajiannya. Demikian pula terhadap penampilan dan harga sagu, hampir seluruhnya $(95,5 \%)$ menyatakan penampilan sagu menarik dan harganya murah. Rasa kaitannya dengan penerimaan suatu makanan, dipandang sebagai faktor utama yang mempengaruhi seseorang dalam memilih makanan yang akan dikonsumsinya (14). Selain faktor rasa, penampilan suatu makanan sangat menentukan tingkat preferensi seseorang terhadap suatu makanan (8). Sifat fisik makanan, termasuk di dalamnya penampilan makanan mempengaruhi selera seseorang yang pada akhirnya menentukan tingkat penerimaan terhadap suatu makanan, sedangkan faktor ketersediaan makanan dalam masyarakat, tingkat kemudahan dalam pengolahan/ penyajian, serta harga suatu makanan sebagai unsur penting yang turut menentukan tingkat preferensi seseorang terhadap suatu makanan (5).

Tingkat preferensi terhadap sagu dalam penelitian ini memberikan perbedaan dalam konsumsi sagu rumah tangga. Rumah tangga yang sangat suka sagu, cenderung mengkonsumsi sagu lebih sering daripada rumah tangga yang hanya suka sagu. 


\section{Persepsi terhadap nilai sosial sagu}

Persepsi dipandang sebagai suatu kesan dari konsumen terhadap suatu objek sebagai akibat dari proses menerima dan memperhatikan serta memahami objek tersebut (15). Suatu objek berupa barang konsumsi yang ada di masyarakat dipersepsikan memiliki nilai sosial tertentu. Jenis barang yang dikonsumsi dapat mencerminkan kelas sosial orang yang mengkonsumsinya (16).

Berbagai makanan dan bahan makanan mempunyai nilai sosial tertentu, karena itu masyarakat akan mengkonsumsi makanan dan bahan makanan tertentu yang memiliki nilai sosial sesuai dengan tingkat naluri pangan yang ada pada masyarakat yang bersangkutan. Masyarakat memberikan penghargaan yang berbeda terhadap berbagai pangan sesuai dengan nilai, adat, dan hubungan sosial yang ada dalam masyarakat yang bersangkutan (5).

Pada penelitian ini, sebagian besar sampel $(74,0 \%)$ mempersepsikan sagu memiliki nilai sosial yang rendah, selebihnya $(26,0 \%)$ mempersepsikan nilai sosial sagu tidak lebih rendah dari bahan pangan pokok lainnya yang biasa dikonsumsi. Sebagian besar rumah tangga menilai pejabat pemerintah dan orang kaya dari segi ekonomi lebih pantas makan nasi daripada sinonggi. Hal ini menunjukkan sagu dianggap bernilai sosial lebih rendah daripada beras oleh rumah tangga yang menilainya.

Dari segi ekonomi dan psikososial, makanan sering digunakan untuk menunjukkan prestise dan status ekonomi, sehingga seseorang akan menilai apa yang wajar dimakan, untuk siapa, dan dalam keadaan yang bagaimana makanan tersebut dihidangkan (17). Berdasarkan persepsi nilai sosial pangan ini, masyarakat membedakan adanya makanan orang kaya dan orang miskin, serta makanan yang dimaksudkan untuk konsumsi hanya dalam lingkungan keluarga, dan makanan yang dihidangkan bila ada tamu terhormat (5).

Penilaian rumah tangga yang menilai sagu dalam bentuk sinonggi tidak layak dihidangkan saat pesta yang diselenggarakan oleh keluarga dan pada saat hari raya seperti hari raya Idul Fitri, menandakan sagu bernilai sosial rendah. Suatu makanan yang bernilai sosial tidak rendah dianggap wajar untuk dihidangkan dalam perayaan-perayaan, hari raya keagamaan, atau pada peristiwa lain yang dianggap penting (18).

Nilai sosial sagu yang dianggap rendah juga tercermin dari pernyataan rumah tangga bahwa harga sagu tidak wajar bila sama atau lebih mahal daripada beras. Cerminan atas penghargaan terhadap suatu makanan dapat diketahui melalui harga dan rasa suatu makanan. Makin enak dan tinggi harga suatu makanan, makin tinggi pula status sosialnya (19).

Hasil pengujian secara statistik menunjukkan bahwa persepsi terhadap nilai sosial sagu memberikan perbedaan dalam konsumsi sagu rumah tangga. Rumah tangga yang mempersepsikan nilai sosial sagu rendah, cenderung lebih jarang mengkonsumsi sagu, sebaliknya rumah tangga yang mempersepsikan nilai sosial sagu tidak rendah, cenderung lebih sering mengkonsumsi sagu.

Hasil dalam penelitian ini menunjukkan bahwa persepsi rumah tangga yang lebih bersifat negatif dalam memandang nilai sosial sagu harus mendapatkan perhatian, karena dapat mempengaruhi konsumsi sagu rumah tangga, yang pada akhirnya dapat menjadi salah satu kendala dalam upaya penganekaragaman bahan pangan pokok.

Rumah tangga yang memberi persepsi rendah terhadap nilai sosial sagu makin besar jumlahnya seiring dengan kemajuan teknologi informasi, terutama radio dan televisi dan makin baiknya jalur transportasi ke daerah lain termasuk ke daerah perkotaan. Kemajuan teknologi informasi menyebabkan penyebaran promosi/iklan produk makanan dapat dijangkau sampai ke pelosok pedesaan, begitu pula dengan kelancaran jalur transportasi yang memudahkan distribusi berbagai produk makanan sampai ke pelosok pedesaan.

Gencarnya promosi dan masuknya berbagai macam makanan, khususnya makanan sumber karbohidrat seperti mie instan, lambat laun akan mempengaruhi konsumsi makanan masyarakat, termasuk di dalamnya konsumsi sagu, terlebih lagi bila masyarakat telah terlanjur memberi persepsi nilai sosial sagu yang rendah.

\section{KESIMPULAN DAN SARAN}

\section{Kesimpulan}

Kedudukan sagu dalam hidangan makanan seharihari rumah tangga sampel sebagai pendamping makanan pokok nasi. Konsumsi sagu pada tingkat rumah tangga berbeda-beda menurut tingkat preferensi, persepsi nilai sosial, dan berdasarkan tingkat ketersediaan sagu di rumah tangga. Variabel ketersediaan sagu di rumah tangga sebagai faktor dominan menentukan konsumsi sagu rumah tangga.

\section{Saran}

Disarankan kepada masyarakat agar pengenalan konsumsi sagu sejak usia dini kepada anak-anak tetap dilakukan untuk pembentukan kebiasaan makan sagu pada usia selanjutnya. Diperlukan pula upaya yang dapat meningkatkan status sosial sagu, seperti pengembangan industri pangan yang menghasilkan produk pangan olahan berbahan baku sagu dengan rasa, penampilan, dan kemasan yang dapat diterima oleh semua lapisan konsumen. Upaya ini di samping dapat meningkatkan status sosial sagu, juga mendorong masyarakat untuk 
membudidayakan sagu dengan lebih baik. Upaya lain yang perlu dilakukan yaitu pengembangan konsep pemasaran sosial seperti kampanye makan sagu dan lomba masak berbahan utama sagu yang dirancang dengan baik oleh pemerintah dan tokoh masyarakat dengan melibatkan masyarakat luas.

\section{RUJUKAN}

1. Hardinsyah, Suhardjo. Kecukupan, Konsumsi, Produksi, dan Pola Pangan Daerah (Provinsi) di Indonesia. Widya Karya Nasional Pangan dan Gizi. Jakarta: LIPI; 1988.

2. Badan Pusat Statistik Provinsi Sulawesi Tenggara. Sulawesi Tenggara dalam Angka. Kendari: BPS Sulawesi Tenggara; 2004.

3. Hidayat TS, Trintrin, Mudjianto TT, Hermina, Luciasari E, Susanto D, et al. Pengembangan Pedoman Menu Makanan Gizi Seimbang Makanan Tradisional di Sulawesi Tenggara dan Nusa Tenggara Timur. Jurnal Penelitian Gizi dan Kesehatan Puslitbang Gizi Bogor 1996;19:42-55.

4. Randall E. Food Preferences as A Determinant of Food Behavior. In: Sanjur D. Sosial and Cultural Perspectives in Nutrition. New York: Prentice-Hall Englewood Cliffs;1982. p. 123-44.

5. Suhardjo. Sosio Budaya Gizi. Bogor: Direktorat Jendral Pendididikan Tinggi PAU Pangan dan Gizi IPB; 1989.

6. Khumaidi M. Gizi Masyarakat. Jakarta: PT BPK Gunung Agung; 1994.

7. Martianto D, Ariani M. Analisis Perubahan Konsumsi dan Pola Konsumsi Pangan Dekade Terakhir. Dalam: Widya Karya Nasional Pangan dan Gizi VIII. Ketahanan Pangan dan Gizi di Era Otonomi Daerah dan Globalisasi. Jakarta: LIPI; 2004. h. 183-207.
8. Sanjur D. Sosial and Cultural Perspectives in Nutrition. New York: Prentice Hall Englewood Cliffs; 1982.

9. Lemeshow S, Hosmer D, Klar J. 1990. Adequacy of Sample Size in Health Studies. (Terjemahan) Pramono D. Yogyakarta: UGM Press; 1997. h. 49-52.

10. Sastroasmoro S. Dasar-Dasar Metodologi Penelitian Klinis. Jakarta: Sagung Seto; 2002.

11. Khumaidi M. Sistem Kewaspadaan Pangan dan Gizi. Bogor: PAU Pangan dan Gizi IPB; 1989.

12. Khomsan A, Nasution A, Riyadi $H$, Anwar F, Sulaeman A. Studi Preferensi Makanan Tradisional di Jawa Tengah, Aceh, dan Sulawesi Selatan Media Gizi dan Keluarga 1996;XX(1):61-7.

13. den Hartog AP, van Staveren WA, Brouwer ID. Manual for Social Surveys on Food Habits and Consumption in Developing Countries. Weikersheim-Germany: Margraf Verlag; 1995.

14. Candraningsih F, Sumarwan U. Preferensi dan Persepsi Konsumen terhadap Makanan Tradisional Sunda. Media Gizi dan Keluarga 1996; XX(1):53-60.

15. Sumarwan U. Perilaku Konsumen: Teori dan Penerapannya dalam Pemasaran. Bogor: Ghalia Indonesia; 2004.

16. Engel JF, Blackwell RD, Miniard PW. Consumer Behavior. Chicago: Dryden Press; 1994.

17. Baliwati YF, Khomsan A, Dwiriani CM. Pengantar Pangan dan Gizi. Jakarta: Penebar Swadaya; 2004.

18. Lowenberg ME, Todhunter EN, Wilson ED, Lubawski JL. Food and Man. New Yorks: John Wiley \& Sons Inc; 1974.

19. Gifft HH, Washbon MB, Harrison GG. Nutrition, Behavior and Change. New Jersey: Prentice-Hall Englewood Cliffs; 1972. 